\title{
Level of Knowledge and Awareness of Pregnant Women about the Coronavirus Pandemic (COVID-19): An Assessment from a Developing Country
}

\section{Gülden Aynaci ${ }^{1}$}

${ }^{1}$ Assoc. Prof., Trakya University, Edirne/Turkey ORCID:0000-0002-2112-8631

E-Mail: guldenaynaci@hotmail.com

Corresponding Author: Gülden Aynacı

January 2022

Volume:19

Issue: 45

DOI:10.26466//opusjsr.1064205

Citation:

Aynac1, G. (2022). Level of

knowledge and awareness of pregnant women about the Coronavirus Pandemic (COVID-

19): An assessment from a developing country. OPUSJournal of Society Research, 19(45),

191-200.

\begin{abstract}
Pregnant women may experience psychological difficulties during the pregnancy experience. Being pregnant during the Covid-19 pandemic process carries pregnancy experiences to a different dimension. Pregnancy is among the vulnerable groups against respiratory tract infections. Health systems support services should be provided to women of reproductive age and pregnant women during the COVID-19 pandemic. This study aims to determine the information needs of pregnant women during the COVID-19 epidemic and to contribute to increasing the quality of health care services to be provided.The sample of this study consisted of 254 pregnant from Trakya University Medical Faculty Obstetrics Clinic in Turkey. The study was conducted from December 2019 to October 2021. Two scales were used in our study. Participants were first evaluated with a personal information form. The scales we used in our study, Perceived Stress Scale-10 (PSS-10), Beck Anxiety Inventory (BAI) were used.In our study; concerns of pregnant women for their own health, their unborn baby (children) and the postpartum period were significantly higher during the COVID-19 pandemic. In addition, the COVID-19 pandemic has demonstrated the need for optimal community use of maternal and child health services. As the time of birth approached, the feeling of pregnant women was increasing.Developing countries may be the weakest part of the chain to stop the spread of current and future epidemics.It is necessary to carry out a well-planned, high-quality and structured training program in order to increase the level of social awareness and contribute to better process management in pregnant women.
\end{abstract}

Key Words: Developing Country, Pregnancy, The Perceived Stress Scale, Coronovirus Pandemic (COVID-19).

Öz

Gebe kadınlar, gebelik deneyimi sırasında psikolojik zorluklar yaşayabilmektedir. Covid- 19 pandemisi sürecinde gebe olmak, gebelik deneyimlerini daha farklı bir boyuta taşımaktadır. Gebelik dönemi solunum yolu enfeksiyonlarına karşı hassas gruplar arasında yer alır. Sağlik sistemleri COVID-19 pandemisinde, üreme çă̆ındaki kadınlara ve gebelere maddi ve manevi destek hizmetleri să̆lanmalıdır. Bu çalışma, COVID-19 salgını sırasında gebelerin, bilgi ihtiyaçlarını belirlemeyi ve verilecek săğlk bakım hizmetlerinde kaliteyi arttırmaya katkı sunmayı amaçlamaktadır.Bu çalışmanın örneklemini Türkiye'deki Trakya Üniversitesi Tip Fakültesi Kadın Hastalıkları Kliniŏi'nden 254 gebe oluşturmuştur.Çalışma Aralık 2019 ile Ekim 2021 tarihleri arasında gerçekleştirilmiştir. Katılımcllar öncelikle kişisel bilgi formu ile değerlendirilmiştir. İki ölçek kullanılmıştır.Çalışmamızda kullandığımız ölçekler, Alg̨lanan Stres Ölçeği-10 (PSS-10), Beck Anksiyete Envanteri (BAI) dir.Çalışmamızda; COVID-19 pandemisi sırasında hamile kadınların kendi sağllkları, doğmamış bebekleri (çocukları) ve doğum sonrası dönemleri ile ilgili endişeleri önemli ölçüde daha yüksekti.Ayrıca, COVID-19 pandemisi, anne ve çocuk săğlğg hizmetlerinin toplum tarafindan optimal kullanımına duyulan ihtiyacı göstermiştir.Doğum zamanı yaklaştıkça hamile kadınların pandemi kaynaklı endişesi artmakta idi.Gelişmekte olan ülkeler, mevcut ve gelecekteki salgınların yayılmasını durdurmak için zincirin en zayıf parçası olabilir.Gebelerde toplumsal farkındalık düzeyinin artırılması ve daha iyi süreç yönetimine katkı sağlanması için iyi planlanmış, kaliteli ve yapılandırılmış kadın sağlı̆̆ı eğitim programlarmin yürütülmesi gerekmektedir.

Anahtar Kelimeler: Gelişmekte Olan Ülkeler, Gebelik, Algılanan Stres Ölçeği, Coronovirus Pandemisi (COVID-19). 


\section{Introduction}

Psychological stress results from an imbalance between an individual's perception and external environmental demands. The studies, psychological stress; It shows that it is closely related to anxiety, depression and physical conditions such as cardiovascular diseases and cancer(Lu et al., 2017a).

Psychological stress reflects a subjective assessment of one's ability to cope with demands. People, their resources and power; When they perceive that they are inadequate to cope with a situation, they experience stress.

During pregnancy, the anxiety and related stress levels described by pregnant women are more common than non-pregnant women, even under normal conditions (Naurin et al., 2021). Before birth; Concerns about the baby's health continue throughout pregnancy. This situation, which has many common points universally; Of course, it manifests differently in different societies (Qiao, 2020). During pregnancy; Anxiety and stress in pregnant women lead to various negativities. At the beginning of these; preterm labor, intrauterine growth retardation, low birth weight. It is also known to be associated with adverse pregnancy outcomes such as early negative responses in postpartum neonates (Qiao, 2020). Some of these risks, by providing a calm and stress-free life during pregnancy; has been shown to decrease.

All countries of the world are facing the third coronavirus crisis in less than two decades. SARS$\mathrm{CoV}$ emerged in 2002 (Zhong et al., 2003), followed by MERS in 2012 (Al-Ahdal, Al-Qahtani, \& Rubino, 2012) and now nCoV (Wuhan) at the end of 2019.

Lessons learned from the days of SARS provide invaluable experiences today. At a remarkable speed; the genome of the Covid-19 virus was sequenced and presented to the public by the China Novel Coronavirus Research and Research Team (Kelvin \& Rubino, 2020; Zhu et al., 2020).

Reciprocal flights from many parts of the world to each other have been cancelled. Many countries have organized special trips to bring their citizens back to their countries from the quarantined areas. However, the steady increase in the number of cases, as well as epidemiologists, hospital staff; forced even the governments of powerful states (Kelvin \& Rubino, 2020; Porcheddu, Serra, Kelvin, Kelvin, \& Rubino, 2020).

The chain of transmission to humans was thought to be zoonotic, with a possible implication. Increasing case numbers and wet wildlife contact and contact investigations for many patients have created a strong case for human-to-human transmission (Kelvin \& Rubino, 2020).

The World Health Organization's (WHO) declaration of a "pandemic" and the identification of third-generation human-to-human transmission have brought back vivid, painful memories of the days of SARS(Ihlen \& Fredriksson, 2018; Naurin et al., 2021).

This is also the case in developing countries; especially women; in the whole society; led to a civil crisis with violence and social anxiety.

Anxiety levels of pregnant women were examined during the COVID-19 pandemic. Studies show that the coronavirus pandemic; demonstrated the potential to increase anxiety in the pregnant population (Gur et al., 2020; Ravaldi, Wilson, Ricca, Homer, \& Vannacci, 2020). However, there were studies evaluating the pregnant population and anxiety prior to the COVID-19 pandemic. One study followed 200 Italian women and found that their feelings of anxiety increased significantly (Ravaldi et al., 2020).

Especially in developing countries; there is a fight against Covid-19 infection for themselves and their families, which most pregnant women have to cope with. Pregnant women are sensitive to stress and the added burden of the pandemic may unfortunately affect them negatively. Indeed, studies have shown high levels of Coronainduced stress and depression in pregnant women in developing countries. 


\section{Research Question and Objectives}

In order to evaluate the mental health status of pregnant women in difficult days in Turkey; We evaluated the perceived stress levels of pregnant women. Perceived stress has not been measured and validated in this population, to our knowledge, in this respect in our country.

\section{Methodology}

\section{Study Design and Participants}

The sample of this descriptive cross-sectional study consisted of 254 pregnant from Trakya UniversityMedical Faculty Obstetrics Clinic in the north west region of Turkey. The study was conducted from December 2019 to October 2021. The age range of the pregnants was 19- 41 years.Participants were given the freedom to terminate the survey anytime.

Participants who did not consent to participate in the study, and/or did not answer the questions of the study, were excluded from the study. Those who have had Covid-19 before themselves or their husbands were not included in our study. Pregnant women who were actively infected with Covid-19 were not included in the study.

\section{Material and Methods}

Two scales were used in our study. Participants were first evaluated with a personal information form. The scales we used in our study, Perceived Stress Scale-10 (PSS-10), Beck Anxiety Inventory (BAI) were used (Beck, Epstein, Brown, \& Steer, 1988)(Leyfer, Ruberg, \& Woodruff-Borden, 2006).

Perceived Stress Scale-10 (PSS-10): The Perceived Stress Scale (PSS) was developed by Cohen, Kamarck and Mermelstein (1983) (Cohen, Kamarck, \& Mermelstein, 1983).

Consisting of 14 items in total, the PSS was designed to measure how stressful some situations in one's life are perceived. Participants evaluate each item on a 5-point Likert-type scale ranging from "Never (0)" to "Very often (4)". 7 of the items with positive expressions are scored in reverse. In addition to its 14-item long form; There are two more forms of PSS as 10 and 4 items (Eskin, Harlak, Demirkıran, \& Dereboy, 2013).

In this study, the PSS-10 scale with 10 questions with proven reliability and validity was applied. The scores of the PSS-10 range from 0 to 40. Getting a high score from the scale; indicates an excess of one's stress perception( $\mathrm{Lu}$ et al., 2017a).

PSS-10 has many advantages in terms of scale. Its main advantages are: 1) it only takes a few minutes and is easy to score; 2 ) items can be easily understood; 3) it is not limited to a specific situation and can be used for past or ongoing events; 4) can be used to study changes over time in response to stressful events; and 5) PSS-10 can be used as an outcome variable(Lu et al., 2017b).

Beck Anxiety Inventory (BAI): In this study, Beck Anxiety Inventory (BAI) was also used to determine anxiety and depression groups. The BAI, Beck et al. (1988) was developed by. It was determined that the scale had sufficient reliability and validity(Beck et al., 1988).

The purpose of the Beck Anxiety Inventory is screening rather than diagnosis. The questions in the Beck anxiety scale are related to anxiety symptoms. The person who answered the test answers the questions by choosing one of four options: "none, mild, moderate, serious". The marking of the options is done by considering the last week.

While scoring the Beck Anxiety Scale, attention is paid to the following: The answers given to the questions in the Beck anxiety scale have scores. None is 0 points, mild is 1 point, moderate is 2 points, and severe is 3 points. At the end of the test, the scores are added up.

1. Mild anxiety symptoms between 8-15 points,

2. Moderate anxiety symptoms between 1625 points,

3. It is categorized as severe anxiety symptoms between $26-63$ points. 


\section{Data sources}

The sociodemographic characteristics, reproductive health and lifestyle behaviours, and knowledge about Covid-19 of the pregnants were assessed using self-report forms. We received written informed consent from the pregnants who participated voluntarily in the study.

\section{Ethical Consideration}

Approval for this study was obtained from Trakya University Medical Faculty Ethics Committee on Scientific Research and informed consents were obtained from all volunteers (Discussion No: E.381804).

\section{Statistical Analysis}

All statistical analyses were performed using the IBM SPSS (Statistical Package for the Social Sciences) 21.0 package program. The normal distribution assumption in the statistical analyses was investigated using the Shapiro-Wilk test.

Student's t-test was used for group comparisons. Relations between categorical variables were investigated using Pearson's Chisquare test. The relationship between the quantitative variables was examined using Pearson's correlation coefficient.

The data were evaluated with appropriate descriptive statistics. Mean and standard deviation were used for quantitative variables and percentage and frequency were used for qualitative variables as descriptive statistics. The level of significance was determined as 0.05 in all statistical analyses.

\section{Results}

This study demonstrated the knowledge level of pregnants in a Turkish University Medical Faculty about Coronavirus infection and vaccines. Among the 254 subjects, $163(64.17 \%)$ were in third trimester and 91 (35.82\%) were in second trimester. More third trimester pregnants were willing to participate in the study than second trimester pregnants.

Pregnants who have routine pregnancy checkups were selected for this study because they constitute a delicate group of society. Acknowledging or understanding the importance of Covid-19; It is easier for pregnant women who have routine pregnancy check-ups than those who do not go to regular obstetricians.

The sociodemographic characteristics of the pregnants were evaluated (Table 1). When the participants are evaluated according to their residence in the village, province or district; There was no statistically significant difference for PSS$10(\mathrm{p}=0.289)$ (Table 1$)$.

254 participants were included in our study. Number of participants in the second trimester was 163; and number of participants in the third trimester.

The mean of the pregnant women in the second trimester for PSS-10 was $27.50( \pm 2,94)$. In terms of PSS-10; there was no statistically significant difference in the second and third trimesters $(p=0.877)$.

It was checked whether there was a relationship between the age of the pregnant women and PSS-10. There was no statistically significant difference $(\mathrm{p}=0.590)$.

When evaluated in terms of the number of previous pregnancies, no statistically significant difference was observed for PSS-10 $(p=0.714)$. The average of primigravida $(\mathrm{n}=70)$ is $27.52( \pm 2.85)$; The average of those with second pregnancy $(n=113)$ was $27.57( \pm 2.75)$; The average of those with third pregnancy $(\mathrm{n}=40)$ was $27.17( \pm 3.76)$; Mean of those with 4 th or more pregnancy $(n=31)$ was $28.03( \pm 0.17)$ (Table 1).

A statistical significance was found for PSS-10 according to the education level of pregnant women $(p=0.024)$.

The school level at which they are the last distance; The PSS-10 score average of those at primary education level $(\mathrm{n}=165)$ was $27.92( \pm$ 1.34). 
The school level they graduated from; The mean score of pregnant women at secondary education level $(n=80)$ was $26.95( \pm 4.14)$. The mean score of the pregnant women who graduated from university $(\mathrm{n}=9)$ was $26.11( \pm$ 5.66).

According to the number of pregnancy followups, no statistical significance was found in relation to the PSS-10 ( $p=0.324)$.

PSS-10 mean score of those who had pregnancy follow-up once in a month $(\mathrm{n}=108)$ was $27.70( \pm 2.30)$.

The average score of those $(n=127)$ who had pregnancy follow-up twice in a month during pregnancy, in state hospitals, was $27.35( \pm 3.32)$.

The average score of those who had pregnancy follow-up three times in a month during pregnancy, $(n=19)$ was $28.05( \pm 0.22)$.

With the systemic blood pressure values of pregnant women; the relationship between PSS-10 was examined. Those who stated that the systemic blood pressure was borderline high during pregnancy $(n=29)$; mean scale score was $27.41( \pm 3.15)$. The mean score of those who used drugs for hypertension during pregnancy $(n=69)$ was $28.01( \pm 0.12)$. The mean PSS-10 score of those who did not experience systemic hypertension during pregnancy $(n=156)$ was $27.37 \quad( \pm 3.29)$. There was no statistically significant difference $(p$ $=0.536$ ).

The characteristics of the participants were examined according to the socioeconomic level. Of 28 pregnant women whose families have a low income; mean PSS-10 score was 28.02 ( \pm 0.55$)$. The PSS-10 score of 23 pregnant women with good family income was 25.78 ( \pm 5.85). Pregnant women who stated that they were at the middle income level; scale mean score $(\mathrm{n}=203)$; It was $27.69( \pm 2.38)$. No statistical significance was found $(\mathrm{p}=0.437)$.

When asked about the occupations in which they mostly make a living, 199 respondents were housewives. The mean PSS-10 score was 28.02 ( \pm 0.02). The mean of 41 pregnant women working in permanent status as civil servants or workers was $28.02( \pm 0.15) .14$ participating tradesmen were self-employed and the average score they got from the scale was $27.42( \pm 3.15)$. Among the 254 subjects, $163(64.17 \%)$ were in third trimester and $91(35.82 \%)$ were in second trimester.

Looking at the values for The BAI; Third trimester mean scores were $24.38( \pm 14.15)$; Second trimester mean scores were $21.49( \pm 11.47)(\mathrm{p}=$ 0.296).With the distribution of the participants according to their geographical regions; there was no significant relationship between both PSS-10 and the BAI $(p=0.354)$ (Table 1$)$.

The BAI averages were evaluated according to their previous pregnancies. BAI scale score of primigravid pregnant women was $21.28( \pm 12.22)$; The BAI score of those with 2nd pregnancy is 24.26 ( \pm 14.19); The score of those with a 3rd pregnancy is $23.20( \pm 11.23)$; The score of those with 4th or more pregnancies was found to be 24.83 ( \pm 14.77). It was observed that BAI scores did not make a significant difference in terms of the number of pregnancies $(p=0.458)$ (Table 1$)$..

There was no significant difference between the BAI scores and the last graduated school levels of the pregnant women $(\mathrm{p}=0.939)$.

Looking at the BAI average; A statistical significance was found according to the number of regular pregnancy follow-ups $(p=0.023)$. The BAI mean score of the pregnant women $(n=108)$ who did not have regular and careful follow-up of pregnancy was $23.53( \pm 12.26)$. The average score of those who followed their routine pregnancy check-ups in state hospitals $(\mathrm{n}=127)$ was $22.07( \pm$ 13.37); The mean score of the pregnant women (n = 19) who had their pregnancy check-ups in private hospitals was $30.73( \pm 16.53)$.

There was no significant relationship between the increase in the number of children they had before and The BAI $(p=0.942)$.

There was no significant relationship between the participants' history of high systemic blood pressure and The BAI $(\mathrm{p}=0.632)$.

When looking at the relationship between The BAI and the socio-economic levels of pregnant women, no significant correlation was found $(\mathrm{p}=$ 0.943) (Table 1).

In our study, the scale scores of the participants were examined according to whether the family attitudes were traditional or modern. A 
statistically significant difference was found in terms of family attitude and The BAI scores $(\mathrm{p}=0.005)$.

The mean BAI score of those with traditional family attitudes $(n=147)$ was $24.89( \pm 13.58)$. The mean BAI score of those with moderate family attitudes $(n=31)$ was $23.19( \pm 14.56)$. The mean BAI score of those with a modern family attitude $(n=76)$ was $20.40( \pm 11.81)$.

Statistically significant difference; were found to be among those with traditional and modern 1) families.When the participants were asked about their profession, 199 people were housewives. The BAI mean score was $24.44( \pm 13.64)$. The average of 41 participants working as civil servants or workers with permanent status was $18.00( \pm 9.31) .14$ people lived with tradesmen or self-employed and their mean scale score was $27.88( \pm 17.73)(\mathrm{p}<0.001)$.

When the relationship between The BAI and the participants' ages was evaluated, no statistically significant relationship was found $(\mathrm{p}=0.463)$ (Table $1)$.

Table 1. Participants were first evaluated with two scale. The scales we used in our study, Perceived Stress Scale-10 (PSS-10), Beck Anxiety Inventory (BAI) were used ( $n=254)$

\begin{tabular}{|c|c|c|c|c|c|}
\hline \multirow[t]{2}{*}{ Parameters } & \multirow{2}{*}{$\frac{\text { Scales }}{\mathrm{n}(\%)}$} & \multicolumn{2}{|l|}{ PSS-10 } & \multicolumn{2}{|l|}{ BAI } \\
\hline & & Mean & $\mathrm{P}$ & Mean & $\mathrm{p}$ \\
\hline \multicolumn{6}{|l|}{ Trimester } \\
\hline Third & $163(64.17 \%)$ & $27.50 \pm 2.94$ & 0.877 & $24.38 \pm 14.15$ & 0.296 \\
\hline Second & $91(35.82 \%)$ & 27.64 & & $21.49 \pm 11.47$ & \\
\hline \multicolumn{6}{|l|}{ Gravida } \\
\hline Primigravid & $70(27.55 \%)$ & $27.52 \pm 2.85$ & 0.714 & $21.28 \pm 12.22$ & 0.458 \\
\hline Second gravid & $113(44.48 \%)$ & $27.57 \pm 2.75$ & & $24.26 \pm 14.19$ & \\
\hline Third gravid & $89(35.03 \%)$ & $27.17 \pm 3.76$ & & $23.20 \pm 11.23$ & \\
\hline Fourth or more & $31(12.20 \%)$ & $28.03 \pm 0.17$ & & $24.83 \pm 14.77$ & \\
\hline \multicolumn{6}{|c|}{ The school level at which they are the last distance } \\
\hline Primary Education & 165 & $27.92 \pm 1.34$ & $0.024^{*}$ & $\underline{23.03 \pm 13.12}$ & 0.939 \\
\hline Secondary Education & 80 & $26.95 \pm 4.14$ & & $23.86 \pm 13.99$ & \\
\hline University & 9 & $26.11 \pm 5.66$ & & $24.44 \pm 12.28$ & \\
\hline \multicolumn{6}{|l|}{ Pregnancy follow-ups } \\
\hline Once in a month & 108 & $27.70 \pm 2.30$ & 0.324 & $23.53 \pm 12.26$ & $0.023^{*}$ \\
\hline Twice in a month & 127 & $27.35 \pm 3.32$ & & $\underline{22.07 \pm 13.37}$ & \\
\hline Three times in a month & 19 & $28.05 \pm 0.22$ & & $30.73 \pm 16.53$ & \\
\hline
\end{tabular}

Systemic blood pressure values during pregnancy

\begin{tabular}{|c|c|c|c|c|c|}
\hline Borderline high & 29 & $27.41 \pm 3.15$ & 0.536 & $24.13 \pm 14.19$ & 0.632 \\
\hline Who used drugs & 69 & $28.01 \pm 0.12$ & & $22.36 \pm 13.75$ & \\
\hline $\begin{array}{l}\text { who did not experience } \\
\text { hypertension }\end{array}$ & 156 & $27.37 \pm 3.29$ & & $23.63 \pm 11.89$ & \\
\hline
\end{tabular}

Socioeconomic level

\begin{tabular}{lllll}
\hline Low income & 28 & $28.00 \pm 0.55$ & 0.437 & $\frac{23.45 \pm 13.72}{21.85 \pm 9.75}$ \\
\cline { 1 - 2 } Middle income & 203 & $27.69 \pm 2.38$ & $\frac{24.943}{24.21 \pm 13.65}$ \\
\hline Good income & 23 & $25.78 \pm 5.85$ & \\
\hline
\end{tabular}

When asked about the professions of pregnant women

\begin{tabular}{llll}
\hline Housewives & 199 & $28.00 \pm 0.02$ & \\
\hline Working in permanent status & 41 & $28.02 \pm 0.15$ & $\frac{24.44 \pm 13.64}{18.00 \pm 9.31}$ \\
\cline { 1 - 2 } Self-employed & 14 & $27.42 \pm 3.15$ & $\frac{18.001^{*}}{27.88 \pm 17.73}$ \\
\hline
\end{tabular}

The participants were examined according to whether the family attitudes were traditional or modern

\begin{tabular}{|c|c|c|c|c|c|}
\hline Traditional family & 147 & $27.43 \pm 3.09$ & 0.437 & $24.89 \pm 13.58$ & $0.005^{*}$ \\
\hline Moderate family & 31 & $27.54 \pm 3.09$ & & $23.29 \pm 14.56$ & \\
\hline Modern family & 76 & $27.78 \pm 1.95$ & & $20.40 \pm 11.81$ & \\
\hline
\end{tabular}

**Perceived Stress Scale-10 (PSS-10), Beck Anxiety Inventory (BAI) 
There was no statistical significance between PSS-10 and the BAI ( $p=0.401)$.

In our study; concerns of pregnant women for their own health, their unborn baby (children) and the postpartum period were significantly higher during the COVID-19 pandemic. In addition, the COVID-19 pandemic has demonstrated the need for optimal community use of maternal and child health services. As the time of birth approached, the feeling of pregnant women was increasing.

Table 2. Evaluation of the scores obtained from the answers given by the participant pregnant women in terms of two different scale scores $(n=254)$

\begin{tabular}{lll}
\hline Scale & BAI & SFI \\
\cline { 2 - 3 } & $\mathbf{p}$ & $\mathbf{p}$ \\
\hline PSS-10 & 0.401 & 0.364 \\
\hline BAI & - & $<0.001^{*}$ \\
\hline
\end{tabular}

${ }^{* *}$ Perceived Stress Scale-10 (PSS-10), Beck Anxiety Inventory (BAI)

These results are valid for Turkey, where confidence in healthcare services has increased during the pandemic. Some subgroups were more concerned about their health than the average pre-pandemic participant. Being at a low socioeconomic level and having a low education level caused more stress in pregnant women. This supports previous studies that concluded that certain groups were particularly exposed to feelings of anxiety during pregnancy (Lebel, MacKinnon, Bagshawe, Tomfohr-Madsen, \& Giesbrecht, 2020). During the pandemic, the only group of pregnant women who were more concerned about their own health were women with a university education level and above. Pandemic among pregnant women, those with low confidence in health services and those with socioeconomic difficulties; led to higher levels of concern for his own health.

\section{Limitations}

Our study is limited by the small sample size; future studies should evaluate this issue using larger sample sizes.

\section{Discussion}

In our study, pregnant women who applied to a University Medical Faculty hospital in Turkey; The perceived stress of pregnant women against the pandemic was evaluated.

Our study was carried out with volunteer pregnant women who came to the obstetrics outpatient clinic in a university hospital in the northwest of Turkey for routine control. It revealed high levels of perceived stress in pregnant women, which correlated with anxiety and depression.

Studies have shown that PSS-10 is significantly and moderately associated with anxiety and depression in participants

Other studies, PSS-10; It has been shown to have concurrent validity with the Beck Depression Inventory ( $\mathrm{Lu}$ et al., 2017b; Wongpakaran \& Wongpakaran, 2010). In our study, too; PSS-10 showed a positive correlation with the BAI in the same direction.

The second important result of this study is in the context of a target-oriented change; It is important in developing the resilience of women who will become mothers against acute situations.

It is necessary to integrate solution-oriented thinking into basic counseling in the education of pregnant women. This model; recommends that pregnant women should be careful about creating a solution-oriented thinking ability instead of spending too much time on problem analysis. Indeed, past research has shown that problemfocused coaching approaches improve well-being and facilitate goal progression; proved to be much less effective than solution-focused approaches (Qiao, 2020).

Many issues regarding the stress level of pregnant women and coping methods have been discussed many times in the literature. However, our current research has evaluated women who may encounter infections in a targeted context.

Our work; even women in society, with new pandemics; against the changing time; It tries to predict the attitudes they will take, whether they are pregnant or not. The women; It is seen that they should adopt an approach that jointly 
develops self-regulation and solution. Birth and having a baby of your own are among the most important events in a woman's life. Naturally, a certain level of concern for the protection of the health of the baby and the mother is seen in all families. However, the most important thing is not to reflect this concern to the pregnant woman. As evidenced by our results, the anxiety levels of pregnant women were high after the onset of the pandemic.

Pregnant women may encounter many sources of stress. All of these can lead to significant psychological dysfunctions. The changing environment, lifestyle changes, material and moral burdens and relationships between spouses are at the forefront in the lives of pregnant women. Parameters affecting pregnant women; is distributed over a wide range (Lu et al., 2017b).

Adding the pandemic process on top of the unique stress of pregnancy; showed the high level of stress of the participants. It is the pandemic process that brings together all these factors (i.e. personal and social changes) that require change and adaptation to life (Naurin et al., 2021). Pregnant women were concerned about both maternal and fetal health. Pandemic; it is a major stressful life event that increases the risk of longterm health deterioration for postpartum women, newborns and even fathers of babies. This is a situation that needs attention at the national and international level.

In maternal or postpartum periods; extra clinical attention should be given to this generation of women, babies, children and partners in medical care visits.

In national and international health events in the field of women's health, diseases and obstetrics; In the context of change, solutionoriented thinking should be provided to facilitate its development (Qiao, 2020).

Developing countries may be the weakest part of the chain to stop the spread of current and future epidemics.

The disease is spreading rapidly, especially in countries where there is insufficient infrastructure to identify the virus using real-time PCR diagnostic tools and public health infrastructure to implement and quarantine (Kelvin \& Rubino, 2020). In order to prevent the deaths of millions of people, priority and adequate investments should be made in these countries.

For satisfactory psychometric results of Turkish pregnant women; we advocate that PSS10 should be widely applied to women receiving health services in other regions of our country.

However, due to differences in cultural levels and social, economic and educational differences between regions; Additional studies should be performed in different geographic regions to confirm the generalizability of our results.

\section{Conclusion}

As a result, we evaluated the stress levels of pregnant women due to Covid-19 in the Turkish cultural context with PSS -10. In addition, in women during pregnancy; We identified high levels of perceived stress due to Covid-19 in situations associated with anxiety and depression.

All of the participants in our study were pregnant women who applied to the 3rd level health institution. But; Studies should also be conducted with pregnant women living in different pregnancy clinics, in different geographies and at different sociocultural levels. Thus, a positive contribution will be made to increase pregnant and maternal health, which is an important area of public health.

Different levels and types of stress can be experienced by women before, during and after pregnancy. This requires different assessments. For example, pregnant women of different intellectual levels may have to cope with psychological stress at different heights due to the accumulated Corona burden and media pressures.

Second, construct validity was limited to reported measure comparisons. Third, we did not assess the discriminant validity of the PSS-10, BAI, in this study. Therefore, in our country and even in the world; These questions must be addressed in various populations. To improve the psychometric quality of the results, objective measures should be applied. 
The results of this study showed that; at the beginning of the social units to be targeted for education programs related to COVID-19; pregnant or reproductive age women. Better quality information is needed on a range of questions to be answered, including the mode of transmission of the virus, symptoms, the incubation period and reinfection and vaccination. For this reason, we think that it is necessary to carry out a well-planned, highquality and structured training program in order to increase the level of social awareness and contribute to better process management in pregnant women.

During the pandemic process, pregnant women and women planning a pregnancy; must follow the instructions of scientists. Avoid close contact with others, especially those who are immunocompromised. Also, frequent hand washing and strict personal hygiene measures are necessary to control virus transmission. This study based on pregnant women; It can provide basic data to the literature for preventive measures in case of future outbreaks. Future studies may investigate important parameters related to SARS-CoV-2 infection in preconception planning. We also suggest investigating the relationship between awareness level and health status of reproductive age, infected and uninfected women.

Acknowledgments:We want to thank to Assoc. Prof. Selçuk Korkmaz for the statical evaluation.

We would like to thank the pregnants for their participation in the study.

Conflict of interests:No conflict of interests is declared.

Financial support:No financial support was received from any person, institution or organization for this study.

\section{References}

Al-Ahdal, M. N., Al-Qahtani, A. A., \& Rubino, S. (2012). Coronavirus respiratory illness in Saudi Arabia. The Journal of infection in developing countries, 6(10), 692-694.
Beck, A. T., Epstein, N., Brown, G., \& Steer, R. A. (1988). An inventory for measuring clinical anxiety: Psychometric properties. Journal of consulting and clinical psychology, 56(6), 893.

Cohen, S., Kamarck, T., \& Mermelstein, R. (1983). A global measure of perceived stress. Journal of health and social behavior, 24(1), 385-396.

Eskin, M., Harlak, H., Demirkıran, F., \& Dereboy, Ç. (2013). Algılanan stres ölçeğinin Türkçeye uyarlanması: güvenirlik ve geçerlik analizi. New Symposium Journal, 51(3), 132-140.

Gur, R. E., White, L. K., Waller, R., Barzilay, R., Moore, T. M., Kornfield, S., . . . ParishMorris, J. (2020). The disproportionate burden of the COVID-19 pandemic among pregnant black women. Psychiatry research, 293, 113475.

Ihlen, Ø., \& Fredriksson, M. (Eds.). (2009). Public relations and social theory: Key figures and concepts (1st ed.). Routledge. https://doi.org/10.4324/9780203883235

Kelvin, D. J., \& Rubino, S. (2020). Fear of the novel coronavirus. The Journal of infection in developing countries, 14(01), 1-2.

Lebel, C., MacKinnon, A., Bagshawe, M., TomfohrMadsen, L., \& Giesbrecht, G. (2020). Elevated depression and anxiety symptoms among pregnant individuals during the COVID-19 pandemic. Journal of affective disorders, 277, 5-13.

Lu, W., Bian, Q., Wang, W., Wu, X., Wang, Z., \& Zhao, M. (2017a). Chinese version of the Perceived Stress Scale-10: A psychometric study in Chinese university students. PloS one, 12(12), e0189543.

Lu, W., Bian, Q., Wang, W., Wu, X., Wang, Z., \& Zhao, M. (2017b). Chinese version of the Perceived Stress Scale-10: A psychometric study in Chinese university students. PloS one, 12(12), e0189543.

Naurin, E., Markstedt, E., Stolle, D., Enström, D., Wallin, A., Andreasson, I., . . . Elden, H. (2021). Pregnant under the pressure of a pandemic: A large-scale longitudinal survey before and during the COVID-19 outbreak. European journal of public health, 31(1), 7-13.

Porcheddu, R., Serra, C., Kelvin, D., Kelvin, N., \& Rubino, S. (2020). Similarity in case fatality rates (CFR) of COVID-19/SARS-COV-2 in 
Italy and China. The Journal of infection in developing countries, 14(02), 125-128.

Qiao, J. (2020). What are the risks of COVID-19 infection in pregnant women? The Lancet, 395(10226), 760-762.

Ravaldi, C., Wilson, A., Ricca, V., Homer, C., \& Vannacci, A. (2021). Pregnant women voice their concerns and birth expectations during the COVID-19 pandemic in Italy. Women and Birth, 34(4), 335-343.

Wongpakaran, N.,\& Wongpakaran, T. (2010). The Thai version of the PSS-10: An investigation of its psychometric properties. BioPsychoSocial medicine, 4(1), 6.

Zhong, N., Zheng, B., Li, Y., Poon, L., Xie, Z., Chan, K., ... Xie, J. (2003). Epidemiology and cause of severe acute respiratory syndrome (SARS) in Guangdong, People's Republic of China, in February, 2003. The Lancet, 362(9393), 1353-1358.

Zhu, N., Zhang, D., Wang, W., Li, X., Yang, B., Song, J., . . . Lu, R. (2020). A novel coronavirus from patients with pneumonia in China, 2019. New England Journal of Medicine, 382, 727-733. 